\title{
Evaluation of bio and polyethylene mulches on soil moisture, soil temperature, weed biomass and Kusmi lac yield on Flemingia semialata, a bushy lac host, in eastern India
}

\author{
R.K. Singh \\ ICAR- Indian Institute of Natural Resins and Gums, Ranchi (Jharkhand) India
}

\begin{abstract}
A field experiment for three consecutive years from 2010 to 2013 was conducted to study the effect of different mulching materials viz., black polyethylene, transparent polyethylene, grass mulch, soil mulch, lac mud and unmulched (control) on soil moisture, soil temperature, weed biomass suppression and Kusmi lac yield of Flemingia semialata under rainfed conditions in the Research farm of ICAR-Indian Institute of Natural Resins and Gums, Ranchi. Results showed the highest soil moisture conservation in black polyethylene by 31.7, 26.7 and 14.4\% over control for the year 2011, 2012 and 2013, respectively. Different mulching materials showed different effects on soil temperature. The maximum mean temperature $\left(21.7^{\circ} \mathrm{C}\right)$ was recorded under transparent polyethylene mulch, while, the lowest soil mean temperature $\left(20.8^{\circ} \mathrm{C}\right)$ was recorded under grass mulch. Mean soil temperature under grass mulch was lower by $1.1,0.7$ and $1.0^{\circ} \mathrm{C}$ compared to transparent mulch for three years, respectively. Black polyethylene suppressed the maximum amount of weed $\left(380.22 \mathrm{~g} \mathrm{~m}^{-2}\right)$, whereas the suppression by transparent mulch was 149.93 $\mathrm{g} \mathrm{m}^{-2}$, which was recorded to be the least. Lac yield showed no definite trend in any of the treatments during the study period.
\end{abstract}

Key Words : Flemingia semialata, Lac yield, Mulches, Soil moisture, Soil temperature, Weed suppression

View Point Article : Singh, R.K. (2018). Evaluation of bio and polyethylene mulches on soil moisture, soil temperature, weed biomass and Kusmi lac yield on Flemingia semialata, a bushy lac host, in eastern India. Internat. J. agric. Sci., 14 (2) : 348-353, DOI:10.15740/HAS/ IJAS/14.2/348-353. Copyright@2018: Hind Agri-Horticultural Society.

Article History : Received : 03.03.2018; Revised : 24.04.2018; Accepted : 10.05.2018

\footnotetext{
* Author for correspondence:

ICAR-Central Arid Zone Research Institute, Jodhpur (Rajasthan) India
} 